\title{
IOWA STATE UNIVERSITY FIELD TRIP REPORT: ECOLOGY AND EVOLUTION IN THE GREATER YELLOWSTONE ECOSYSTEM
}

\section{DIANE M. DEBINSKI $\uparrow$ ROBERT KLAVER $\downarrow$ DEPARTMENT OF ECOLOGY, EVOLUTION AND ORGANISMAL BIOLOGY $\uparrow$ IOWA STATE UNIVERSITY $\uparrow$ AMES, IA}

\section{JULIE BLANCHONG $\uparrow$ SUE FAIRBANKS $\uparrow$ DEPARTMENT OF NATURAL RESOURCES ECOLOGY AND MANAGEMENT $\uparrow$ IOWA STATE UNIVERSITY $\uparrow$ AMES, IA}

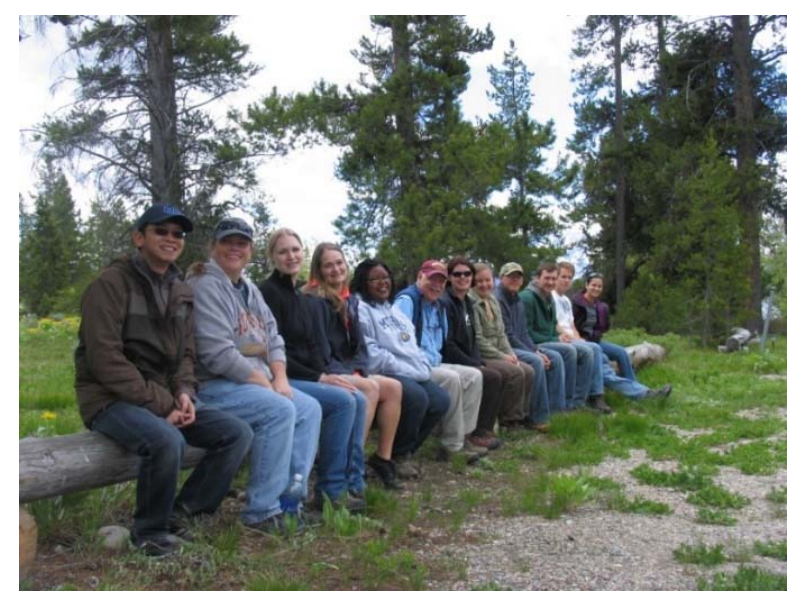

Figure 1. Iowa State University EEB Fieldtrip participants at UW-NPS Research Station, June 2013. In order from left to right: Jer Pin Chong, Lynne Gardner, Hannah Julich, Amy Podaril, Karri Folks, Bob Klaver, Julie Blanchong, Tatyana Flick, John Delaney, Ryan Williams, Brent Mortensen, and Melissa Telemeco (photo by Diane Debinski).

\section{$\uparrow$ COURSE DESCRIPTION}

Iowa State University's graduate program in Ecology and Evolutionary Biology (EEB) requires that all graduate students participate in one field trip class during their graduate career. In this 2 credit class students learn about the ecology of the ecosystem that they will be visiting via seminars and lectures during the semester. The classroom teaching culminates in a field trip experience. During the field trip the students have an opportunity to meet local scientists, researchers, land managers and representatives from non-government agencies. They then write up a summary of their work and are graded on these activities.

The 2013 EEB fieldtrip was led by Drs. Diane Debinski, Julie Blanchong, Bob Klaver, and
Sue Fairbanks. Ten graduate students participated in the field trip focused on the Greater Yellowstone Ecosystem (Figure 1).

The Greater Yellowstone Ecosystem (GYE) is one of the largest intact ecosystems in the continental U.S. However, it faces pressures from extractive industries, ecotourism, disease, and burgeoning population growth. The goal of this course was to familiarize the students with some of the ecological, social, and political issues related to managing this ecosystem. We met during the 2013 spring semester as a seminar group to inform ourselves about some of these issues. Then in June of 2013, we took a 10 day field trip to the GYE to explore some of these lands and organisms. Our team was housed for four nights at the University of Wyoming-National Park Service Research Station. We also spent two nights in cabins 
near Gardner, Montana interacting with staff of the Yellowstone Institute. From these sites, we conducted day hikes through a variety of habitat types (forest, alpine, riparian, geyser basins, etc.) and met with biologists and conservationists representing organizations such as the National Park Service, the U.S. Forest Service, U.S. Geological Survey, Northern Rocky Mt. Science Center, Teton Science School, Wyoming Game and Fish Department, and the Greater Yellowstone Coalition. Some of the issues that our group explored included:

- Management of brucellosis and chronic wasting disease relative to bison and elk both in the parks and within the surrounding landscape

- The status of the wolf reintroduction program - Case studies: trophic structure before and after wolves came back; delisting/hunting issues; sarcoptic mange

- Protection of genetic biodiversity housed in hot springs of Yellowstone National Park, birth place of Thermus aquaticus, used in PCR techniques

- $\quad$ Potential effects of global climate change in the GYE - Case studies: pine beetles, pikas, forest change, and grizzly populations
- Warming waters and native trout

- Invasive species

- The role of fire in maintaining biodiversity

- The debate over wilderness designation of national forest lands in the GYE

- Water quality issues and the protection of geothermal resources

- Phosphate and gold mining, oil extraction, and wind power - Case study: sage grouse.

\section{CONCLUSIONS AND ACKNOWLEDGEMENTS}

The class went very well and we appreciated the opportunity to spend time at the UW-NPS Research Station and to interact with the broad array of researchers and managers who work within the ecosystem.

\begin{tabular}{|c|c|c|c|}
\hline \multicolumn{4}{|c|}{ Field Trip Itinerary } \\
\hline Date & Location & Event & Location for the night \\
\hline $\begin{array}{l}\text { May } 31 \\
\text { (Friday) }\end{array}$ & $\begin{array}{l}\text { ISU Transportation } \\
\text { Services parking lot }\end{array}$ & Pack vehicles & Ames \\
\hline $\begin{array}{l}\text { June } 1 \\
\text { (Saturday) }\end{array}$ & $\begin{array}{l}\text { Ames, IA to points } \\
\text { westward }\end{array}$ & Westward ho! & Cheyenne WY \\
\hline $\begin{array}{l}\text { June } 2 \\
\text { (Sunday) }\end{array}$ & $\begin{array}{l}\text { Point westward to Moran } \\
\text { WY }\end{array}$ & Drive to UW-NPS & $\begin{array}{l}\text { UW-NPS Research } \\
\text { Station, Moran, WY }\end{array}$ \\
\hline $\begin{array}{l}\text { June } 3 \\
\text { (Monday) }\end{array}$ & $\begin{array}{l}\text { AMK Grand Teton } \\
\text { National Park }\end{array}$ & $\begin{array}{l}\text { Hank Harlow - morning welcome to AMK, hibernation } \\
\text { physiology talk. } \\
\text { Hike/canoe near station } \\
\text { Deb Patla \& Kelly McCloskey- wetland restoration \& } \\
\text { amphibians }\end{array}$ & $\begin{array}{l}\text { UW-NPS Research } \\
\text { Station, Moran, WY }\end{array}$ \\
\hline $\begin{array}{l}\text { June } 4 \\
\text { (Tuesday) }\end{array}$ & Grand Teton NP & $\begin{array}{l}\text { Renee Seidler } 9 \text { a.m. AMK - wolverines; } \\
\text { Diane Debinski - climate change experiment Pilgrim Creek } \\
\text { Aly Courtemanch -evening presentation, bighorn sheep and } \\
\text { migration routes }\end{array}$ & $\begin{array}{l}\text { UW-NPS Research } \\
\text { Station, Moran, WY }\end{array}$ \\
\hline $\begin{array}{l}\text { June } 5 \\
\text { (Wednesday) }\end{array}$ & Old Faithful, Hot Springs & $\begin{array}{l}\text { Drive through YNP, stop at hot springs to learn about } \\
\text { archebacteria }\end{array}$ & $\begin{array}{l}\text { UW-NPS Research } \\
\text { Station, Moran, WY }\end{array}$ \\
\hline $\begin{array}{l}\text { June } 6 \\
\text { (Thursday) }\end{array}$ & $\begin{array}{l}\text { Hayden Valley, Norris } \\
\text { Hot Springs }\end{array}$ & $\begin{array}{l}\text { Drive through YNP, } \\
\text { discussion with Paul Cross (USGS) at Mammoth ( } \sim 2 \text { p.m.) } \\
\text { about bison, elk, and disease }\end{array}$ & $\begin{array}{l}\text { Yellowstone Institute, } \\
\text { Gardiner, MT }\end{array}$ \\
\hline $\begin{array}{l}\text { June } 7 \\
\text { (Friday) }\end{array}$ & Yellowstone Institute & $\begin{array}{l}\text { Yellowstone Institute Programming } \\
\text { (wildlife viewing and hike in Lamar Valley) }\end{array}$ & $\begin{array}{l}\text { Yellowstone Institute, } \\
\text { Gardiner, MT }\end{array}$ \\
\hline $\begin{array}{l}\text { June } 8 \\
\text { (Saturday) }\end{array}$ & Drive eastward & Drive from Gardiner, MT and stop in Chamberlin, SD & Chamberlain, SD \\
\hline $\begin{array}{l}\text { June } 9 \\
\text { (Sunday) }\end{array}$ & Drive home & Drive SD to IA & Ames \\
\hline
\end{tabular}

